\title{
Theoretical Investigation into the Solvent Effect on the Thermal Decomposition of RDX in Tetrahydrofuran, Acetone, Toluene and Benzene
}

Fu-de Ren ( $\sim$ renfude@hotmail.com )

College of Chemical Engineering and Environment

\section{Xiong Cao}

North University of China

Yun-tong Cui

Zhengzhou University of Light Industry

\section{Research Article}

Keywords: solvent effect on thermal decomposition of explosive, intermolecular hydrogen exchange, explosive sensitivity, M06-2X, surface electrostatic potentials

Posted Date: October 5th, 2021

DOl: https://doi.org/10.21203/rs.3.rs-900765/v1

License: (a) (1) This work is licensed under a Creative Commons Attribution 4.0 International License. Read Full License

Version of Record: A version of this preprint was published at Journal of Molecular Modeling on November 5th, 2021. See the published version at https://doi.org/10.1007/s00894-021-04966-z. 


\title{
Theoretical investigation into the solvent effect on the thermal decomposition of RDX in tetrahydrofuran, acetone, toluene and benzene
}

\author{
Fu-de Ren ${ }^{\mathrm{a},{ }^{*}}, \quad$ Xiong $\mathrm{Cao}^{\mathrm{b}}$, Yun-tong $\mathrm{Cui}^{\mathrm{c}}$ \\ ${ }^{a}$ School of Chemical Engineering and Technology, North University of China, Taiyuan 030051, China \\ ${ }^{\mathrm{b}}$ School of Environment and Safety Engineering, North University of China, Taiyuan 030051, China \\ ${ }^{c}$ College of Art and Design, Zhengzhou University of Light Industry, Zhengzhou 450002, China
}

\begin{abstract}
In order to clarify the solvent effect on the thermal decomposition of explosive, the $\mathrm{N}-\mathrm{NO}_{2}$ trigger-bond strengths and ring strains of $\mathrm{RDX}$ (cyclotrimethylenetrinitramine) in its H-bonded complexes with solvent molecules (i.e., tetrahydrofuran, acetone, toluene and benzene), and the activation energies of the intermolecular hydrogen exchanges between the solvent molecules and $\mathrm{C}_{3} \mathrm{H}_{8} \mathrm{O}_{2} \mathrm{~N}_{4}$ or $\mathrm{CH}_{4} \mathrm{O}_{2} \mathrm{~N}_{2}$, as the model molecule of $\mathrm{RDX}$, were investigated by the BHandHLYP, B3LYP, MP2(full) and M06-2X methods with the 6-311++G(2df,2p) basis set, accompanied by a comparison with the calculations by the integral equation formalism polarized continuum model. The solvent effects ignore the ring strain while strengthen the $\mathrm{N}-\mathrm{NO}_{2}$ bond, leading to a decreased sensitivity, as is opposite to the experimental results. However, the activation energies are in the order of $\mathrm{C}_{3} \mathrm{H}_{8} \mathrm{O}_{2} \mathrm{~N}_{4} / \mathrm{CH}_{4} \mathrm{O}_{2} \mathrm{~N}_{2} \cdots$ acetone $<\mathrm{C}_{3} \mathrm{H}_{8} \mathrm{O}_{2} \mathrm{~N}_{4} / \mathrm{CH}_{4} \mathrm{O}_{2} \mathrm{~N}_{2} \cdots$ THF $<\mathrm{C}_{3} \mathrm{H}_{8} \mathrm{O}_{2} \mathrm{~N}_{4} / \mathrm{CH}_{4} \mathrm{O}_{2} \mathrm{~N}_{2} \cdots$ toluene $<\mathrm{C}_{3} \mathrm{H}_{8} \mathrm{O}_{2} \mathrm{~N}_{4} / \mathrm{CH}_{4} \mathrm{O}_{2} \mathrm{~N}_{2} \cdots$ benzene $<\mathrm{C}_{3} \mathrm{H}_{8} \mathrm{O}_{2} \mathrm{~N}_{4} / \mathrm{CH}_{4} \mathrm{O}_{2} \mathrm{~N}_{2}$, suggesting that the order of the critical explosion temperatures should be RDX *acetone < RDX $\cdots \mathrm{THF}<\mathrm{RDX} \cdots$ toluene $<$ RDX $\cdots$ benzene $<\mathrm{RDX}$, as is roughly consistent with the experimental results. Therefore, the intermolecular hydrogen exchange with the HONO elimination is the essence of the solvent effect on the thermal decomposition of RDX. The solvent effect is confirmed by reduced density gradient, atoms in molecules and surface electrostatic potentials.
\end{abstract}

Keywords: solvent effect on thermal decomposition of explosive, intermolecular hydrogen exchange, explosive sensitivity, M06-2X, surface electrostatic potentials

\footnotetext{
* Corresponding author. Address: College of Chemical Engineering and Technology, North University of China, Taiyuan 030051, China; Tel.: +86 351 3922117; fax: +86 351 3922117; E-mail address: fdren888@126.com (F. Ren).
} 


\section{Introduction}

With the development of science and military technology, both belligerents always strive to destroy each other's military powers with the most advanced equipments. The safety of the weapon and ammunition is seriously threatened by the stability of explosives. The nitramine explosives containing the polynitro groups are the main components of the ammunition in service, and exploring the mechanism of the thermal decomposition of them is the key to improve their stabilities and reduce thermal sensitivities [1,2].

RDX (cyclotrimethylenetrinitramine, see Fig. 1) is one of the important nitroamine explosives. It has been shown from the experiments that the gas-phase reaction mechanism of the initial thermal decomposition of RDX may be the $\mathrm{N}-\mathrm{NO}_{2}$ bond dissociation [3], loss of the mono-oxygen atom of the nitro group [4], rearrangement reaction of the nitro group [5] or ring-opening reaction [6,7]. In theoretical investigations, these four mechanisms have also attracted great attention. Melius et al. [8] investigated the gas-phase thermal decomposition of RDX by $a b$ initio calculation for the first time, and found that the $\mathrm{N}-\mathrm{NO}_{2}$ bond was broken at high temperature while the HONO elimination occurred at low temperature. With the B3LYP/6-311G(d,p) and G2 methods, Harris et al. [9] drew a conclusion that the $\mathrm{N}-\mathrm{NO}_{2}$ bond dissociation was the initial reaction, and then the decomposition reaction occurred through the hydrogen transfer. According to the results from the calculations with the MP2、G2 and CBS-Q methods, Dorset et al. [10] predicated that the $\mathrm{C}-\mathrm{N}$ bond fracture was impossible. By $a b$ initio and density functional theory (DFT) methods, Habibollahzadeh et al. [11] found that a competitive reaction occurred between the symmetrical ring-opening reaction and $\mathrm{N}-\mathrm{NO}_{2}$ bond dissociation, with the formation of three methylene nitramines, which was consistent with the 
experimental result by Liu et al. [3]. Wu et al. [12] calculated the bond dissociation energy (BDE) of the $\mathrm{N}-\mathrm{NO}_{2}$ bond and the ring-opening energy of the symmetric ring-breaking by DFT, and concluded that the dissociation pathway of the $\mathrm{N}-\mathrm{NO}_{2}$ bond was the main pathway of the decomposition reaction, which was consistent with the semi-empirical PM3 calculation by Pivina et al. [13]. Chakraborty et al. [14] studied the $\mathrm{N}-\mathrm{NO}_{2}$ bond dissociation, $\mathrm{HONO}$ elimination and symmetrical ring-opening by using the B3LYP/6-31G (d) method, and found that the BDE of the $\mathrm{N}-\mathrm{NO}_{2}$ bond and activation energy of the $\mathrm{HONO}$ elimination reaction were 39.0 and $39.2 \mathrm{kcal} / \mathrm{mol}$ respectively. A conclusion was drawn that, although the BDE of the $\mathrm{N}-\mathrm{NO}_{2}$ bond was lower, the large amount of the energies were required for the further reactions, and thus the $\mathrm{HONO}$ elimination was the dominant decomposition pathway.

Solvent has a significant effect on the thermal decomposition. Although the solvent effect on the initial thermal decomposition of RDX have aroused great interest in experiments for more than 30 years [15], the reaction mechanism is still unclear. According to the phenomenon that the activation volume of the thermal decomposition of RDX in tetrahydrofuran (THF) under high pressure was negative, which was just contrary to the fact that the activation volume of the homolytic reaction of the $\mathrm{N}-\mathrm{NO}_{2}$ bond should be positive, Wang et al. [1] proposed the mechanism of eliminating HONO through a five-membered-ring transition state. Hoffsommer et al [15] observed the effect of the solvent isotopes for the thermal decomposition of RDX in benzene. Shu et al. [16] investigated the solvent effects on the thermal decomposition of RDX by a Bourdon manometer with the concentration in the range of $0.1 \%-2 \%$ of RDX. The results showed that benzene, isooctane and naphthalene did not affect the decomposition rate of RDX, while it was increased in the aliphatic-aromatic solvents, such as ketones, alcohols, ethers and esters, etc., and 
inhibited in the solvents with the large viscosity. Furthermore, the solvent effect was explained on basis of the $\mathrm{N}-\mathrm{NO}_{2}$ bond dissociation with a secondary reaction [17].

There may be, in essence, two kinds of mechanisms for the solvent effects on the chemical reactions. One is that the molecular conformation or structure is changed by the solvent effect originated from the intermolecular interaction between the solute and solvents molecules, resulting in the strength change of the activative bond, and thus the change of the activation energy or the reaction path of the thermal decomposition. For example, it has been confirmed that the "trigger bonds", which are broken to initiate explosive decomposition [18], could be changed by the solvent effects in experiments $[19,20]$. It is firstly reported in the theoretical investigation by our group that the strength of the $\mathrm{C}-\mathrm{NO}_{2}$ trigger bond was strengthened upon the formation of the intermolecular $\mathrm{H}$-bonding interaction between $\mathrm{HF}$ with $\mathrm{CH}_{3} \mathrm{NO}_{2}$, nitrotriazole or its methyl derivatives [21,22], and due to the solvent effect of $\mathrm{H}_{2} \mathrm{O}$ and formamide, the $\mathrm{N}-\mathrm{NO}_{2}$ trigger bond of $\mathrm{HMX}$ (cyclotetramethylenetetranitramine) was strengthened [23]. We also found that, for nitrocyclopropane, nitrocyclobutane, nitrocyclopentane and nitrocyclohexane, the ring strain energy was decreased upon the formation of the complex with the solvent molecule [24]. The other is that the solvent molecule could participate in the chemical reactions with the solute molecule, leading to the change of the activation energy or reaction path.

Thus, there may be two kinds of the initial reaction mechanisms for the solvent effects on the thermal decomposition of RDX. One is that the trigger-bond strength of the $\mathrm{N}-\mathrm{NO}_{2}$ bond or the tension strength of the ring are changed induced by the intermolecular interaction between the solvent and RDX molecules. The other is that the solvent reacts with RDX, leading to the change of pathway or barrier. To our knowledge, however, although a lot of investigations have been carried out to reveal 
the essence of the initial reaction mechanisms of the thermal decomposition of RDX in solution in experiments, the solvent effect, i.e., the effect of the intermolecular interaction between the solvent and RDX molecules or the chemical reaction involving the solvent molecule, on the initial thermal decomposition of RDX is rarely reported in theory.

In order to reveal the essence of the solvent effect on the initial thermal decomposition of RDX, in this work, the changes of the $\mathrm{N}-\mathrm{NO}_{2}$ bond strengths and ring strains upon the formation of the intermolecular interactions between RDX and solvent molecules THF, acetone, toluene or benzene, as well as the activation energies of the intermolecular hydrogen exchange reactions (leading to the possible HONO elimination) between the model molecule of RDX and above solvent molecules were investigated. This investigation is important to choose the solvents to reduce thermal sensitivities and expand the applications of the high energetic explosives.

\section{Computational details}

All calculations were performed with Gaussian 03 programs [25]. The monomers and complexes were fully optimized at the BHandHLYP/6-311++G(2df,2p) level, and the stable structures $(\mathrm{NImag}=0)$ were obtained, accompanied by a comparison with the calculations by the integral equation formalism polarized continuum model (IEFPCM) based on the self-consistent-reaction-field (SCRF) [26] with THF ( $\varepsilon=7.58)$, acetone $(\varepsilon=20.7)$, toluene $(\varepsilon=2.568)$ and benzene $(\varepsilon=2.275)$. The intermolecular interactions were calculated at the BHandHLYP/6-311++G(2df,2p), B3LYP/6-311++G(2df,2p), MP2(full)/6-311++G(2df,2p) and M06-2X/6-311++G(2df,2p) levels, respectively, and corrected with the basis set superposition error (BSSE) [27,28]. The BDEs of the $\mathrm{N}-\mathrm{NO}_{2}$ bonds involving the intermolecular interactions were calculated:

$$
B D E=E_{(\mathrm{R} \cdot)}+E_{\left(\cdot \mathrm{NO}_{2}\right)}-E_{\mathrm{RDX}} \quad \text { for RDX monomer }
$$




$$
B D E=E_{(\mathrm{R} \cdot)}+E_{\left(\cdot \mathrm{NO}_{2} \cdots \text { solvent }\right)}-E_{(\mathrm{RDX} \cdots \text { solvent })} \quad \text { for complex }
$$

$\mathrm{R} \cdot$ and "RDX $\cdots$ solvent" mean the radical that RDX or RDX $\cdots$ solvent lose a $\mathrm{NO}_{2}$ radical, and the RDX complex with the solvent molecule, respectively.

According to the designed hyperhomodesmotic reactions [29-31], i.e., (3) and (4), the ring strain energies $\left(E_{\mathrm{RS}}\right)$ were calculated by the equation $E_{\mathrm{RS}}=\sum E_{\mathrm{R}}-\sum E_{\mathrm{P}}$, where $E_{\mathrm{R}}$ and $E_{\mathrm{P}}$ mean the energy of the reactant and product, respectively.

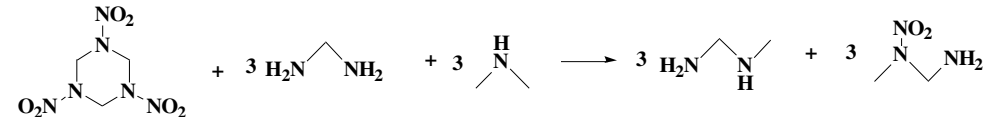

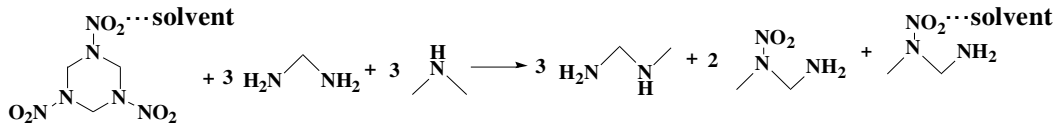

For the dynamic calculations, $\mathrm{C}_{3} \mathrm{H}_{8} \mathrm{O}_{2} \mathrm{~N}_{4}$ (see Fig. 1) was selected as a model compound of RDX with one axial $-\mathrm{NO}_{2}$ group. All the reactants (R), transition states (TS) and products (P) were optimized using the BHandHLYP method with the compound basis set, where the elements $\mathrm{O}$ and $\mathrm{H}$ involving the intermolecular hydrogen exchange were used the $6-311++\mathrm{G}(2 \mathrm{df}, 2 \mathrm{p})$ basis set while the $6-311+\mathrm{G}(\mathrm{d})$ was employed to the elements $\mathrm{C}$ and $\mathrm{N}$. In most cases, it is very difficult to obtain the TS structures at the molecular energy hypersurfaces with the tight SCF convergence of $10^{-8}$, the loose SCF convergence had to be used. As a comparison, the dynamic calculations involving the reactions of $\mathrm{CH}_{4} \mathrm{O}_{2} \mathrm{~N}_{2}$ (as another model molecule of RDX with one $-\mathrm{NO}_{2}$ group, see Fig. 1) with the solvent molecules were also carried out, and the TS was confirmed by the imaginary frequency at the BHandHLYP/6-311++G(2df,2p) level of theory. The activation energies were obtained at the BHandHLYP/6-311++G(2df,2p), B3LYP/6-311++G(2df,2p), MP2(full)/6-311++G(2df,2p) and M06-2X/6-311++G(2df,2p) levels of theory.

The rate constants were calculated at the BHandHLYP/6-311++G(2df,2p) level by the conventional transition state theory (CTST) $[32,33]$ as following: 


$$
k(T)=\kappa(T) \frac{k_{B} T}{h} \exp \left(-\frac{\Delta G^{ \pm}}{R T}\right)
$$

where $k_{\mathrm{B}}, T, h, \Delta \mathrm{G}^{\neq}$, and $R$ are the Boltzmann constant, absolute temperature, Planck's constant, Gibbs energy of activation and the universal gas constant, respectively. Wigner tunneling correction factor $\kappa(\mathrm{T})$ [34] was calculated according to the deviations from CTST from the tunneling effect [35]:

$$
\kappa(T)=1+\frac{1}{24}\left[\frac{h \operatorname{Im}\left(v^{\ddagger}\right)}{k_{B} T}\right]^{2}
$$

where $\operatorname{Im}\left(v^{\ddagger}\right)$ is the imaginary frequency corresponding to the transition state.

The analyses of the AIM (atoms in molecules) [36], reduced density gradient (RDG) [37] and surface electrostatic potentials [38] were carried out by the Multiwfn programs [39] at the BHandHLYP/6-311++G(2df,2p) level.

\section{Results and discussion}

Intermolecular interaction, $\mathrm{BDE}$ of the $\mathrm{N}-\mathrm{NO}_{2}$ bond and ring strain

\section{Structure of the complex}

Since the RDX conformation, in which the six-membered ring is a chair form with two axial and one equatorial $-\mathrm{NO}_{2}$ groups (signed as “AAE” $\mathrm{RDX}$ ), is the most stable [40], it is considered to build the complex with THF, acetone, toluene and benzene, respectively. For each of the systems, the most stable intermolecular H-bonded complex is obtained (see Fig. 1). In RDX $\cdots$ THF, the H atom of the methylene group of THF points to the axial $-\mathrm{NO}_{2}$ group, and in $\mathrm{RDX} \cdots$ acetone the $\mathrm{H}$ atom of the methyl group of acetone points to the axial $-\mathrm{NO}_{2}$ group. In these two complexes, the $\mathrm{O}$ atom points to the $\mathrm{H}$ atom of RDX. In RDX $\cdots$ toluene and RDX $\cdots$ benzene, the $\mathrm{H}$ atom of the methyl group of toluene and that on the benzene ring point to the axial $-\mathrm{NO}_{2}$ group, respectively. The most shortest distances of the $\mathrm{H} \cdots \mathrm{O} \mathrm{H}$-bonds are in the 
order of RDX $\cdots$ acetone $<$ RDX $\cdots$ THF $<$ RDX $\cdots$ toluene $<$ RDX $\cdots$ benzene.

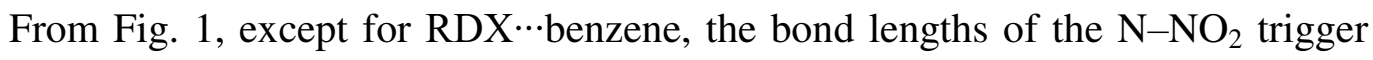
bond in complexes are all shorter than that in the isolated RDX, suggesting that the $\mathrm{N}-\mathrm{NO}_{2}$ bond turns strong upon the complex formation. The decrease in RDX $\cdots$ acetone or RDX $\cdots$ THF is the most notable, up to about 0.022 and $0.038 \AA$, respectively. In RDX $\cdots$ toluene, the decrease is only $0.006 \AA$, while it is almost not changed in $\mathrm{RDX} \cdots$ benzene. These results are in agreement with those from the IEFPCM, with the decrease of $0.018,0.026,0.011$ or $-0.003 \AA$ in the RDX complex with THF, acetone, toluene or benzene.

\section{Intermolecular interaction and $\mathrm{BDE}$ of the $\mathrm{N}-\mathrm{NO}_{2}$ bond}

From Table 1, in most cases, the intermolecular interaction energies calculated using the BHandHLYP and B3LYP methods are larger than those obtained from the MP2(full) and M06-2X methods. Due to the consideration of the dispersion corrections [41-43], the intermolecular H-bonding interaction energies at the M06-2X/6-311++G(2df,2p) level are close to those with the MP2(full)/6-311++G(2df,2p) method. At four levels of theory, the interaction energies decrease in magnitude in the same order of RDX $\cdots$ acetone > RDX $\cdots \mathrm{THF}>$ RDX $\cdots$ toluene > RDX $\cdots$ benzene, as is in accordance with the results from the structures.

From Table 2, the BDEs calculated using the B3LYP method are close to those obtained from the M06-2X. According to the literatures [44,45], B3LYP is suitable to estimate the BDEs since the serious spin contamination can be negligible, with the $\left\langle S^{2}>\right.$ value of 0.75 in this work. At four levels of theory, the orders of the BDEs of the $\mathrm{N}-\mathrm{NO}_{2}$ bond are $\mathrm{RDX} \cdots$ acetone $>\mathrm{RDX} \cdots \mathrm{THF}>\mathrm{RDX} \cdots$ toluene $>\mathrm{RDX} \cdots$ benzene $\approx$ RDX. The BDEs of the $\mathrm{N}-\mathrm{NO}_{2}$ bond in complexes are all larger than that of the 
isolated (pure) $\mathrm{RDX}$, indicating that the $\mathrm{N}-\mathrm{NO}_{2}$ bond is strengthened upon the formation of intermolecular interaction, as is similar to the previous investigations $[21,22,46]$. From Table 2, although the values of BDEs from the IEFPCM based on the IEFPCM are larger than those from the intermolecular H-bonded explexes, and the order of the intermolecular interactions from two methods is inconsistent, the fact that the $\mathrm{N}-\mathrm{NO}_{2}$ bond is strengthened in the presence of the solvent molecule is confirmed. Thus, it is more difficult for the $\mathrm{N}-\mathrm{NO}_{2}$ bond of $\mathrm{RDX}$ to be broken in the presence of the solvent molecule.

\section{Ring strain}

In order to clarify the solvent effect on the ring-opening reaction, the ring perimeters and ring strain energies of the RDX complexes with the different solvent molecules were investigated.

The ring perimeter means the sum of the bond lengths of six $\mathrm{C}-\mathrm{N}$ bonds of ring. From Fig. 1, the ring perimeter changes very slightly, no more than $0.010 \AA$ upon the formation of the complex. Furthermore, the changes of six bond angles in ring (i.e., $\angle(\mathrm{CNC}))$ are also slight, no more than $2.0^{\circ}$ upon the complex formation.

The ring strain energies $\left(E_{\mathrm{RS}}\right)$ at four levels of theory are in Table 3 . The $E_{\mathrm{RS}}$ values of pure RDX (monomer) are in the range of $90.8 \sim 100.9 \mathrm{~kJ} / \mathrm{mol}(88.2 \mathrm{~kJ} / \mathrm{mol}$ with the BLYP/DNP method [47]). At each of the levels of theory, the ring strain energies of RDX in the complexes are very close to that of the RDX monomer, no more than $15.0 \mathrm{~kJ} / \mathrm{mol}$.

The ignorable changes of the ring perimeters, bond angles in ring and ring strain energies upon the complex formations indicate that the solvent effect on the ring strain can be negligible, and there is almost no the solvent effect on the ring-opening reaction. 
In order to obtain the deeper insight into the solvent effect on the thermal decomposition of RDX, the analyses of RDG, AIM and surface electrostatic potentials were carried out.

RDG is a fundamental dimensionless quantity which can be used to detect non-covalent interactions in real space based on the electron density [37]. The plots of RDG versus $\operatorname{sign}\left(\lambda_{2}\right) \rho$ of the complexes are shown Fig. 2. There is obvious difference between the complexes RDX $\cdots$ acetone/THF and RDX $\cdots \mathrm{RDX}$ in the shape and quantity of spikes or troughs of the low-density and low-gradient negative regions of $\operatorname{sign}\left(\lambda_{2}\right) \rho$ (attraction interaction). Therefore, according to the Hohenberg-Kohn theorem [48], there is essential difference in the type of the interaction between the complexes RDX $\cdots$ acetone/THF and RDX $\cdots$ RDX. In RDX $\cdots$ RDX, RDX $\cdots$ benzene and RDX $\cdots$ toluene, the low-density and low-gradient regions correspond to the $\mathrm{C}-\mathrm{H} \cdots \mathrm{O}-\mathrm{N}$ H-bonding interactions, while in RDX $\cdots$ acetone and RDX $\cdots \mathrm{THF}$, the low-density and low-gradient regions mainly correspond to the $\mathrm{C}-\mathrm{H} \cdots \mathrm{O}=\mathrm{C}$, $\mathrm{C}-\mathrm{H} \cdots \mathrm{O}-\mathrm{C}$ and $\mathrm{C}-\mathrm{H} \cdots \mathrm{O}-\mathrm{N}$ H-bonding interactions.

According to the AIM results, in each of the complexes, there is always a bond path linking the $\mathrm{O}$ atom of the $-\mathrm{NO}_{2}$ group with the $\mathrm{H}$ atom of the $-\mathrm{CH}$ group, accompanied by a bond critical point (BCP) $(3,-1)$ (see Fig. 3). The electron densities $\rho_{\mathrm{BCP}}$ are within the range of $0.0029 \sim 0.0113$ a.u., and their laplacians $\nabla^{2} \rho_{\mathrm{CCP}}$ are positive, suggesting the closed-shell $\mathrm{H}$-bonding $\mathrm{C}-\mathrm{H} \cdots \mathrm{O}-\mathrm{N}$ interactions. In RDX $\cdots$ acetone and RDX $\cdots$ THF, the $\mathrm{C}-\mathrm{H} \cdots \mathrm{O}=\mathrm{C}$ and $\mathrm{C}-\mathrm{H} \cdots \mathrm{O}-\mathrm{C}$ interactions are also confirmed according to the bond critical points $(\mathrm{BCP})(3,-1)$ and the corresponding positive laplacians. The larger the electron density $\rho$ at the bond saddle point, the stronger the interaction is. For RDX $\cdots$ acetone, RDX $\cdots$ THF, RDX $\cdots$ toluene and 
RDX $\cdots$ benzene, the values of the electron densities $\rho$ involving the $\mathrm{C}-\mathrm{H} \cdots \mathrm{O}=\mathrm{C}$, $\mathrm{C}-\mathrm{H} \cdots \mathrm{O}-\mathrm{C}$ and $\mathrm{C}-\mathrm{H} \cdots \mathrm{O}-\mathrm{N}$ interactions are $0.0152,0.0128,0.0103,0.0052$ a.u., respectively, indicating that the intermolecular interactions are in the order of RDX $\cdots$ acetone $>$ RDX $\cdots \mathrm{THF}>\mathrm{RDX} \cdots$ toluene $>$ RDX $\cdots$ benzene, as is in agreement with the result from the structure and interaction energy.

Particular attention is the AIM results in six $\mathrm{C}-\mathrm{N}$ bonds of $\mathrm{RDX}$ and $\mathrm{N}-\mathrm{NO}_{2}$ trigger bonds. Compared with the RDX monomer, for each of the complexes there is almost no obvious change in the $\rho$ value of the $\mathrm{C}-\mathrm{N}$ bond, suggesting that the solvent effect on the ring strain can be negligible, and the solvent has almost no effect on the ring-opening reaction. However, except for RDX $\cdots$ benzene, the $\rho$ values of the $\mathrm{N}-\mathrm{NO}_{2}$ bond in complexes $(0.3640 \sim 0.3812$ a.u. $)$ are larger than that of the RDX monomer ( 0.3625 a.u.), suggesting that the strength of the $\mathrm{N}-\mathrm{NO}_{2}$ bond is enhanced upon the formation of the complexes RDX $\cdots$ acetone, RDX $\cdots$ THF or RDX $\cdots$ toluene. Thus, the explosive sensitivity of RDX is decreased in solution.

In order to obtain the deeper insight into the solvent effect on the strength of the $\mathrm{N}-\mathrm{NO}_{2}$ bond and ring strain, the surface electrostatic potentials on the 0.001 a.u. molecular surface of the RDX and its complexes were investigated (see Fig. 4). Most of the surface minima $\left(V_{\mathrm{S}, \mathrm{min}}\right)$ are associated with the $\mathrm{O}$ atom or the $-\mathrm{NO}_{2} \pi$-electron group, and the surface maxima $\left(V_{\mathrm{S}, \max }\right)$ are located near to the $\mathrm{H}$ atom.

For the energetic compounds with the ring, Politzer, Murray, Rice and Klapötke et al. have predicted theoretically that, the more positive the electrostatic potential in the central region of ring, the high the sensitivity [49-53]. For example for the CL-20/TNT complex, the positive electrostatic potential in the cage of CL-20 was diminished, and thus the sensitivity of complex was decreased [54]. From Fig. 4, compared with the RDX monomer, there is almost no obvious change in the positive 
electrostatic potential in the central region of ring, suggesting that the solvent effect on the ring strain could be ignored, as is in agreement with the result from the structure and strain energy.

Politzer et al. have found that, the more positive the electrostatic potential above the $\mathrm{N}-\mathrm{NO}_{2}$ trigger-bond, the weaker the bond becomes and the higher the explosive sensitivity is $[50,51]$. The local maxima above the axial $\mathrm{N}-\mathrm{NO}_{2}$ bonds $\left(V_{\mathrm{s}, \max (\mathrm{N}-\mathrm{NO} 2)}\right)$ are 18.25 and $19.71 \mathrm{kcal} / \mathrm{mol}$ in $\mathrm{RDX}$ monomer, while for the $\mathrm{N}-\mathrm{NO}_{2}$ bonds involving the intermolecular interactions, they are in range of $8.27 \sim 15.62 \mathrm{kcal} / \mathrm{mol}$ in the RDX frameworks of the complexes. The values of $V_{\mathrm{s}, \max (\mathrm{N}-\mathrm{NO} 2)}$ in the RDX frameworks are less than those in $\mathrm{RDX}$ monomer, indicating that the $\mathrm{N}-\mathrm{NO}_{2}$ bond strength is enhanced upon the formation of the complex. Thus, the explosive sensitivity is reduced in complex.

In sum, upon the formation of the RDX complex with the solvent molecule, although the ring strain is almost not changed, the $\mathrm{N}-\mathrm{NO}_{2}$ bond is strengthened due to the solvent effect. The larger energy has to be consumed to counteract the BDE of the $\mathrm{N}-\mathrm{NO}_{2}$ bond and break the $\mathrm{N}-\mathrm{NO}_{2}$ bond during the initiation process, leading to the decreased thermal sensitivity. Thus, upon the formation of the RDX complex with the solvent molecule, the critical explosion temperature should be increased, as is just opposite to the result of the experimental critical explosion temperatures of RDX in the presence of above four solvent [55]. The critical explosion temperature of the pure RDX is $213.7^{\circ} \mathrm{C}$, while those of RDX in THF, acetone, toluene and benzene are 193.8, 195.7, 205.5 and $212.9^{\circ} \mathrm{C}$, respectively. Therefore, the changes of the BDEs of the $\mathrm{N}-\mathrm{NO}_{2}$ bond or the ring strains induced by the solvent effect can not be used to explain the experimental critical explosion temperatures of RDX in solution. In other words, the mechanism of the initial thermal decomposition of RDX in solution is not 
the $\mathrm{N}-\mathrm{NO}_{2}$ bond dissociation or ring-opening reaction.

Intermolecular hydrogen exchange

As mentioned above, the mechanism of the initial thermal decomposition of RDX in solutions is not the $\mathrm{N}-\mathrm{NO}_{2}$ bond dissociation or ring-opening reaction. In order to determine whether the mechanism is the HONO elimination induced by the solvent effect or not, the intermolecular hydrogen exchanges between the solvent molecule and $\mathrm{C}_{3} \mathrm{H}_{8} \mathrm{O}_{2} \mathrm{~N}_{4}$ or $\mathrm{CH}_{4} \mathrm{~N}_{2} \mathrm{O}_{2}$ were investigated.

Chakraborty et al. [14] carried out a theoretical investigation into the thermal decomposition of RDX, and the intramolecular hydrogen transference was determined. They found that the $\mathrm{H}$ atom of the axial $\mathrm{C}-\mathrm{H}$ bond could be transferred to the axial $-\mathrm{NO}_{2}$ group through a five-membered-ring $\mathrm{TS}_{\mathrm{RDX}}$, and then a HONO elimination reaction occurred (see Fig. 5). Similar to the intramolecular hydrogen transference, the intermolecular hydrogen exchanges between solvent molecule and $\mathrm{C}_{3} \mathrm{H}_{8} \mathrm{O}_{2} \mathrm{~N}_{4}$ or $\mathrm{CH}_{4} \mathrm{~N}_{2} \mathrm{O}_{2}$ were studied.

For the intermolecular hydrogen exchange between $\mathrm{C}_{3} \mathrm{H}_{8} \mathrm{O}_{2} \mathrm{~N}_{4}$ and THF, the H-bonded complex $\mathrm{C}_{3} \mathrm{H}_{8} \mathrm{O}_{2} \mathrm{~N}_{4} \cdots \mathrm{THF}$ was considered as the reactant. The $\mathrm{H}$ atom of the axial $\mathrm{C}-\mathrm{H}$ bond in $\mathrm{C}_{3} \mathrm{H}_{8} \mathrm{O}_{2} \mathrm{~N}_{4}$ is transferred to the $\mathrm{C}$ atom of the $-\mathrm{CH}_{2}$ group in the ortho position of the $\mathrm{O}$ atom of THF, and simultaneously the $\mathrm{H}$ atom of this group in THF is transferred to the $\mathrm{O}$ atom of the axial $-\mathrm{NO}_{2}$ group in $\mathrm{C}_{3} \mathrm{H}_{8} \mathrm{O}_{2} \mathrm{~N}_{4}$ via a transition state $\mathrm{TS}_{\mathrm{C} 3 \mathrm{H} 8 \mathrm{O} 2 \mathrm{~N} 4 \cdots \mathrm{THF}}$ (see Fig. 5). At four levels of theory, the barriers of $\mathrm{TS}_{\mathrm{RDX} \cdots \mathrm{THF}}$ are lower than the BDEs of the $\mathrm{N}-\mathrm{NO}_{2}$ bond in the $\mathrm{C}_{3} \mathrm{H}_{8} \mathrm{O}_{2} \mathrm{~N}_{4} \cdots \mathrm{THF}$ complex (see Table 4), indicating that the intermolecular hydrogen exchange occurs preferentially in the initial decomposition process, as is similar to the decomposition of $\mathrm{CH}_{3} \mathrm{NO}_{2}$ in the $\mathrm{CH}_{3} \mathrm{NO}_{2} \cdots \mathrm{H}_{2} \mathrm{O}$ system [56]. The similar preferential intermolecular hydrogen exchange also occurs in $\mathrm{C}_{3} \mathrm{H}_{8} \mathrm{O}_{2} \mathrm{~N}_{4} \cdots$ toluene system, in which the $\mathrm{H}$ atom of 
the axial $\mathrm{C}-\mathrm{H}$ bond in $\mathrm{C}_{3} \mathrm{H}_{8} \mathrm{O}_{2} \mathrm{~N}_{4}$ is transferred to the $\mathrm{C}$ atom of the $-\mathrm{CH}_{3}$ group in toluene, and simultaneously the $\mathrm{H}$ atom of the $-\mathrm{CH}_{3}$ group in toluene is transferred to the axial $-\mathrm{NO}_{2}$ group of $\mathrm{C}_{3} \mathrm{H}_{8} \mathrm{O}_{2} \mathrm{~N}_{4}$. Unfortunately, the TS of the intramolecular hydrogen transference of $\mathrm{C}_{3} \mathrm{H}_{8} \mathrm{O}_{2} \mathrm{~N}_{4}$ was not found despite the great efforts. By the potential energy scanning at the BHandHLYP/6-311++G(2df,2p) level, the barrier of the intramolecular hydrogen transference is about $185.0 \mathrm{~kJ} / \mathrm{mol}$, larger than that of intermolecular hydrogen exchange in $\mathrm{C}_{3} \mathrm{H}_{8} \mathrm{O}_{2} \mathrm{~N}_{4} \cdots$ THF or $\mathrm{C}_{3} \mathrm{H}_{8} \mathrm{O}_{2} \mathrm{~N}_{4} \cdots$ toluene system, confirming again that intermolecular hydrogen exchange occurs preferentially.

It is well known that the keto-enol tautomerism exists in ketones. The transition state of the keto-enol tautomerism for acetone was found, with a low barrier of 138.7 $\mathrm{kJ} / \mathrm{mol}$ at the BHandHLYP/6-311++G(2df,2p) level. Thus, for the intermolecular hydrogen exchange between $\mathrm{C}_{3} \mathrm{H}_{8} \mathrm{O}_{2} \mathrm{~N}_{4}$ and acetone, the enol structure was considered. The axial $\mathrm{H}$ atom in $\mathrm{C}_{3} \mathrm{H}_{8} \mathrm{O}_{2} \mathrm{~N}_{4}$ is transferred to the $\mathrm{C}$ atom of the $=\mathrm{CH}_{2}$ group in the enol acetone, and simultaneously the $\mathrm{H}$ atom of the $-\mathrm{OH}$ group in acetone is transferred to the axial $-\mathrm{NO}_{2}$ group of $\mathrm{C}_{3} \mathrm{H}_{8} \mathrm{O}_{2} \mathrm{~N}_{4}$. At four levels of theory, the barriers involving $\mathrm{TS}_{\mathrm{C} 3 \mathrm{H} 8 \mathrm{O} 2 \mathrm{~N} 4 \cdots a \text { acetone }}$ are also lower than the BDEs of the $\mathrm{N}-\mathrm{NO}_{2}$ bond or the barrier of the intramolecular hydrogen transference of $\mathrm{C}_{3} \mathrm{H}_{8} \mathrm{O}_{2} \mathrm{~N}_{4}$, indicating the preferential intermolecular hydrogen exchange.

For $\mathrm{C}_{3} \mathrm{H}_{8} \mathrm{O}_{2} \mathrm{~N}_{4} \cdots$ benzene, the TS of the intermolecular hydrogen exchange was not found. By the potential energy scanning, the barrier of the similar intermolecular hydrogen exchange between $\mathrm{C}_{3} \mathrm{H}_{8} \mathrm{O}_{2} \mathrm{~N}_{4}$ and benzene was obtained to be about 280.0 $\mathrm{kJ} / \mathrm{mol}$ at the BHandHLYP/6-311++G(2df,2p) level.

From Table 4, at four levels of theory, the barriers involving the hydrogen exchanges are in the order of $\mathrm{C}_{3} \mathrm{H}_{8} \mathrm{O}_{2} \mathrm{~N}_{4} \cdots$ acetone $<\mathrm{C}_{3} \mathrm{H}_{8} \mathrm{O}_{2} \mathrm{~N}_{4} \cdots$ THF $<$ $\mathrm{C}_{3} \mathrm{H}_{8} \mathrm{O}_{2} \mathrm{~N}_{4} \cdots$ toluene $<\mathrm{C}_{3} \mathrm{H}_{8} \mathrm{O}_{2} \mathrm{~N}_{4} \cdots$ benzene, suggesting that order of the barriers are 
RDX $\cdots$ acetone $<$ RDX $\cdots$ THF $<$ RDX $\cdots$ toluene $<$ RDX $\cdots$ benzene. Thus, the order of

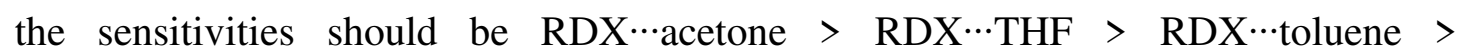
RDX $\cdots$ benzene and that of the critical explosion temperatures should be RDX $\cdots$ acetone $<$ RDX $\cdots$ THF $<$ RDX $\cdots$ toluene $<$ RDX $\cdots$ benzene, as is roughly in accordance with that of the experimental results (i.e., RDX $\cdots$ acetone $\approx$ RDX $\cdots \mathrm{THF}<$ RDX $\cdots$ toluene $<$ RDX $\cdots$ benzene [55]). Furthermore, except for $\mathrm{C}_{3} \mathrm{H}_{8} \mathrm{O}_{2} \mathrm{~N}_{4} \cdots$ benzene, the barrier of the hydrogen exchange between $\mathrm{C}_{3} \mathrm{H}_{8} \mathrm{O}_{2} \mathrm{~N}_{4}$ and the solvent molecule is lower than that of the intramolecular hydrogen transference of $\mathrm{C}_{3} \mathrm{H}_{8} \mathrm{O}_{2} \mathrm{~N}_{4}$, suggesting that the sensitivity of RDX is increased and the critical explosion temperature is decreased in the presence of solvent acetone, THF or toluene, as is also in accordance with the experimental result [55]. Therefore, the intermolecular hydrogen exchange between RDX and the solvent molecule, accompanied by the next step of the HONO elimination, is the mechanism of the thermal decomposition of RDX in solution. The same conclusion can also be drawn from the the dynamic calculations of the $\mathrm{CH}_{4} \mathrm{~N}_{2} \mathrm{O}_{2}$ systems with above four solvent molecules, shown by the fact that the barriers involving the hydrogen exchanges are in the order of $\mathrm{CH}_{4} \mathrm{~N}_{2} \mathrm{O}_{2} \cdots$ acetone < $\mathrm{CH}_{4} \mathrm{~N}_{2} \mathrm{O}_{2} \cdots$ THF $<\mathrm{CH}_{4} \mathrm{~N}_{2} \mathrm{O}_{2} \cdots$ toluene $<\mathrm{CH}_{4} \mathrm{~N}_{2} \mathrm{O}_{2} \cdots$ benzene (see Fig. 5 and Table 4). These explain the experimental results that benzene did not affect the decomposition rate of RDX while it was increased in ketones, alcohols and ethers, etc. [16].

\section{Conclusions}

In order to clarify the solvent effect on the thermal decomposition of explosive, the changes of the $\mathrm{N}-\mathrm{NO}_{2}$ bond strengths and ring strains upon the formation of the intermolecular H-bonding interactions between RDX and solvent molecules, as well as the activation energies of the intermolecular hydrogen exchange reactions between the model molecule of RDX and solvent molecules were investigated, accompanied 
by a comparison with the calculations by the IEFPCM based on the SCRF method.

Upon the formation of the RDX complex with the solvent molecule, although the ring strain is almost not changed, the $\mathrm{N}-\mathrm{NO}_{2}$ bond is strengthened due to the solvent effect. The larger energy has to be consumed to counteract the BDE of the $\mathrm{N}-\mathrm{NO}_{2}$ bond and break the $\mathrm{N}-\mathrm{NO}_{2}$ bond during the initiation process, leading to the decreased thermal sensitivity, as is just opposite to the experimental results. Therefore, the changes of the BDEs of the $\mathrm{N}-\mathrm{NO}_{2}$ bond or the ring strains induced by the solvent effect can not be used to explain the experimental critical explosion temperatures of RDX in solution. The mechanism of the initial thermal decomposition of RDX in solution is not the $\mathrm{N}-\mathrm{NO}_{2}$ bond dissociation or ring-opening reaction.

However, the activation energies of the intermolecular hydrogen exchanges are in the order of $\mathrm{C}_{3} \mathrm{H}_{8} \mathrm{O}_{2} \mathrm{~N}_{4} / \mathrm{CH}_{4} \mathrm{O}_{2} \mathrm{~N}_{2} \cdots$ acetone $<\mathrm{C}_{3} \mathrm{H}_{8} \mathrm{O}_{2} \mathrm{~N}_{4} / \mathrm{CH}_{4} \mathrm{O}_{2} \mathrm{~N}_{2} \cdots$ THF $<$ $\mathrm{C}_{3} \mathrm{H}_{8} \mathrm{O}_{2} \mathrm{~N}_{4} / \mathrm{CH}_{4} \mathrm{O}_{2} \mathrm{~N}_{2} \cdots$ toluene $\quad<\quad \mathrm{C}_{3} \mathrm{H}_{8} \mathrm{O}_{2} \mathrm{~N}_{4} / \mathrm{CH}_{4} \mathrm{O}_{2} \mathrm{~N}_{2} \cdots$ benzene $<$ $\mathrm{C}_{3} \mathrm{H}_{8} \mathrm{O}_{2} \mathrm{~N}_{4} / \mathrm{CH}_{4} \mathrm{O}_{2} \mathrm{~N}_{2}$, suggesting that the order of the critical explosion temperatures should be RDX $\cdots$ acetone $<$ RDX $\cdots$ THF $<$ RDX $\cdots$ toluene $<$ RDX $\cdots$ benzene $<$ RDX, as is roughly consistent with the experimental results. Therefore, the intermolecular hydrogen exchange, accompanied by the next step of the HONO elimination, is the essence of the solvent effect on the thermal decomposition of RDX, by which some experimental results could be explained.

This investigation is important to choose the solvents to reduce thermal sensitivities and expand the applications of the high energetic explosives.

\section{Funding}

The authors are grateful for the financial support from the Shanxi Province Natural Science Foundation of China (No. 201801D121067). 


\section{Conflicts of interest}

The authors declare no competing financial interest.

\section{Ethical Statement}

We allow the journal to review all the data, and we confirm the validity of results. There is none of the financial relationships. This work was not published previously and it is not submitted to more than one journal. It is also not split up into several parts to submit. No data have been fabricated or manipulated.

\section{Consent to participate}

All the authors (Fu-de Ren, Xiong Cao and Yun-tong Cui) agree to participate in this investigation.

\section{Consent for publication}

All the authors agree to publish the manuscript.

\section{Availability of data and material}

We confirm the availability of all the data and materials in this manuscript. The manuscript has full control of all primary data, and the authors agree to allow the journal to review their data if requested.

\section{Code availability}

N/A

\section{Authors' contributions}

Fu-de Ren: Project administration, Investigation, Writing - original draft (Introduction, Theoretical framework and Computational details and Conclusions), review \& editing. 
Xiong Cao: Conceptualization, Calculation and Data curation, Data analysis and technical graphics.

Yun-tong Cui: Part of the calculations, Figure processing for AIM, RDG and Surface electrostatic potentials.

\section{References}

1. Wang J, Brower KR, Naud DL (1997) Evidence of an elimination mechanism in thermal decomposition of RDX and related compounds under high pressure in solution. J Org Chem 62: 9055-9060.

2. Oxely JC, Kooh AB, Szekeres R, Zheng W (1994) Mechanism of nitramine thermolysis. J Phys Chem 98:7004-7008.

3. Liu ZR, Liu Y, Fan XP, Zhao FQ (2006) Thermal decomposition of RDX and HMX explosives part III: mechanism of thermal decomposition, Chin J Expl Propell 29:14-18

4. Behrens R (1987) Simultaneous thermogravimetric modulated beam mass spectrometry and time-of-flight velocity spectra measurements: thermal decomposition mechanisms of RDX and HMX. 24th JANNAF combustion meeting, 1:333.

5. Stewart PH, Jeffries JB, Zellweger JM, McMillen DF, Golden DM (1989) Molecular beam sampled laser pyrolysis of dimethylnitramine. J Phys Chem 93:3557-3563 .

6. Farber M, Srivastava RD (1979) Mass spectrometric investigation of the thermal decomposition of RDX. Chem Phys Lett 64: 307-310.

7. Farber M, Srivastava RD (1981) Mass spectrometric studies of the thermal decomposition of 1,3,5,7-tetranitro-1,3,5,7-tetraazacyclooctane (HMX). Chem Phys Lett 80:345-349.

8. Melius CF (1990) In Chemistry and Physics of Energetic Materials. Bulusu SN, Ed, Kluwer Dordrecht, $\mathrm{P} 21$

9. Harris NJ, Lammertsma K (1997) Ab initio density functional computations of conformations and bond dissociation energies for hexahydro-1,3,5-trinitro-1,3,5-triazine. J Am Chem Soc 119:6583-6589.

10. Dorset H, White A (2000) Overview of molecular modeling and ab initio molecular orbital 
methods suitable for use with energetic materials. Defence Science and Technology Organisation, Salisbury (Australia), P32-35.

11. Habibollahzadeh D, Grodzicki M, Seminario JM, Politzer P (1991) Computational study of the concerted gas-phase triple dissociations of 1,3,5-trazacyclohexane and its 1,3,5-trinitro derivative. J Phys Chem A 95:7699-7702.

12. Wu CJ, Fried LE (1997) Ab initio study of RDX decomposition mechanisms. J Phys Chem A 101:8675-8679.

13. Pivina TS, Sokerina EV, Lushnikov DE (1999) Computer modeling of probable decomposition reactions: cyclonitramines. Propell Explos Pyrot 24:99-107.

14. Chakraborty D, Muller RP, Dasgupta S, Goddard III WA (2000) The mechanism for unimolecular decomposition of RDX (1,3,5-trinitro-1,3,5-triazine), an ab initio study. J Phys Chem A 104:2261-2272.

15. Hoffsommer JC, Glover DJ (1985) Thermal decomposition of 1,3,5-trinitro-1,3,5-triazacyclohexane (RDX): Kinetics of nitroso intermediates formation. Combust Flame 59: 303-310.

16. Shu YJ, Dubikhin VV, Nazin GM, Manelis GB (2000) Effect of solvents on thermal decomposition of RDX, Chin J Energ Mater 8:108-110.

17. Shu YJ, Dubikhin VV, Nazin GM, Manelis GB (2001) Thermal decomposition mechanism of RDX in inertial solvents, Chin J Expl Propell 4:58-60.

18. Shoaf AL, Bayse CA (2018) Trigger bond analysis of nitroaromatic energetic materials using wiberg bond indices. J Comput Chem 19:1236-1248.

19. Yang L, Zhang J, Zhang TL, Zhang JG, Cui Y (2009) Crystal structures, thermal decompositions and sensitivity properties of $\left[\mathrm{Cu}(\text { ethylenediamine })_{2}(\text { nitroformate })_{2}\right]$ and $\left.[\text { Cd(ethylenediamine })_{3}\right](\text { nitroformate })_{2}$. J Hazard Mater 164:962-967.

20. Buszewski B, Michel M, Cudziło S, Chyłek Z (2009) High performance liquid chromatography of 1,1-diamino-2,2-dinitroethene and some intermediate products of its synthesis. J Hazard Mater 164:1051-1058.

21. Wang H-B, Shi W-J, Ren F-D, Yang L, Wang J-L (2012) A B3LYP and MP2(full) theoretical investigation into explosive sensitivity upon the formation of the intermolecular 
hydrogen-bonding interaction between the nitro group of $\mathrm{RNO}_{2}\left(\mathrm{R}=-\mathrm{CH}_{3},-\mathrm{NH}_{2},-\mathrm{OCH}_{3}\right)$ and $\mathrm{HF}, \mathrm{HCl}$ or $\mathrm{HBr}$. Comput Theor Chem 994:73-80.

22. Li B-H, Shi W-J, Ren F-D, Wang Y (2013) A B3LYP and MP2(full) theoretical investigation into the strength of the $\mathrm{C}-\mathrm{NO}_{2}$ bond upon the formation of the intermolecular hydrogen-bonding interaction between HF and the nitro group of nitrotriazole or its methyl derivatives. J Mol Model 19:511-519.

23. Meng, Rui-hong; Cao, Xiong; Hu, Shuang-qi; Hu, Li-shuang (2017) Theoretical insight into the solvent effect of $\mathrm{H}_{2} \mathrm{O}$ and formamide on the cooperativity effect in HMX complex. J Mol Model 23:237.

24. Qiu W, Ren F-D, Shi W-J, Wang Y-H (2015) A theoretical study on the strength of the C-NO bond and ring strain upon the formation of the intermolecular H-bonding interaction between HF and nitro group in nitrocyclopropane, nitrocyclobutane, nitrocyclopentane or nitrocyclohexane. J Mol Model 21:114-122.

25. Frisch MJ, Trucks GW, Schlegel HB, Scuseria GE, Robb MA, Cheeseman JR, Scalmani G, Barone V, Mennucci B, Petersson GA, Nakatsuji H, Caricato M, Li X, Hratchian HP, Izmaylov AF, Bloino J, Zheng G, Sonnenberg JL, Hada M, Ehara M, Toyota K, Fukuda R, Hasegawa J, Ishida M, Nakajima T, Honda Y, Kitao O, Nakai H, Vreven T, Montgomery JA, Jr, Peralta JE, Ogliaro F, Bearpark M, Heyd JJ, Brothers E, Kudin KN, Staroverov VN, Kobayashi R, Normand J, Raghavachari K, Rendell A, Burant JC, Iyengar SS, Tomasi J, Cossi M, Rega N, Millam JM, Klene M, Knox JE, Cross JB, Bakken V, Adamo C, Jaramillo J, Gomperts R, Stratmann RE, Yazyev O, Austin AJ, Cammi R, Pomelli C, Ochterski JW, Martin RL, Morokuma K, Zakrzewski VG, Voth GA, Salvador P, Dannenberg JJ, Dapprich S, Daniels AD, Farkas O, Foresman JB, Ortiz JV, Cioslowski J, Fox DJ (2009) Gaussian 09, Inc.. USA: Wallingford CT.

26. Tomasi J, Mennucci B, Cammi R (2005) Quantum mechanical continuum solvationmodels. Chem Rev 105:2999-3093.

27. Duijineveldt FB, Duijineveldt-van de Rijdt JCMV, Lenthe JHV (1994) State of the art in counterpoise theory. Chem Rev 94:1873-1885.

28. Boys SF, Bernardi F (1970) The calculation of small molecular interactions by the differences 
of separate total energies. Some procedures with reduced errors. Mol Phys 19:553-566.

29. Wheeler SE, Houk KN, Von RSP, Allen WD (2009) A hierarchy of homodesmotic reactions for thermochemistry. J Am Chem Soc 131:2547-2560.

30. Gimarc BM, Zhao M (1997) Strain and resonance energies in main-group homoatomic rings and clusters. Coord Chem Rev 158:385-412.

31. Wodrich MD, Gonthier JF, Steinmann SN, Corminboeuf C (2010) How Strained are Carbomeric-Cycloalkanes?. J Phys Chem A 114:6705-6712.

32. Steinfeld JI, Fransisco JS, Hase WL (1999) Chemical Kinetics and Dynamics, Prentice Hall, New Jersey, 2nd edn.

33. Arabi AA, Matta CF (2011) Effects of external electric fields on double proton transfer kinetics in the formic acid dimer. Phys. Chem Chem Phys 13:13738-13748.

34. Wigner EP (1932) Über das überschreiten von potential schwellen bei chemischen reaktionen. Z Phys Chem B 19 (1932) 203-216.

35. Eyring H, Eyring EM (1963) Modern Chemical Kinetics, Reinhold Publishing Corporation, New York, 1963.

36. B.-König FW, Bader RFW, Tang TH (1982) Calculation of the average properties of atoms in molecules. II. J Comput Chem 3:317-328.

37. Johnson ER, Keinan S, Mori-Sánchez P, Contreras-García J, Cohen AJ, Yang W (2010) Revealing Noncovalent Interactions. J Am Chem Soc 132:6498-6506.

38. Politzer P, Murray JS (2015) Some molecular/crystalline factors that affect the sensitivities of energetic materials: molecular surface electrostatic potentials, lattice free space and maximum heat of detonation per unit volume. J Mol Model 21:25-35.

39. Lu T (2014) Multiwfn: a multifunctional wavefunction analyzer, Version 3.3.5. Beijing.

40. Choi CS, Prince E (1972) The crystal structure of cyclotrimethylenetrinitramine. Acta Crystallogr Sect B 28:2857-2862.

41. Singla P, Riyaz M, Singhal S, Goel N (2016) Theoretical study of adsorption of amino acids on graphene and BN sheet in gas and aqueous phase with empirical DFT dispersion correction. Phys Chem Chem Phys 18:5597-5604.

42. Soniat M, Rogers DM, Rempe SB (2015) Dispersion-and exchange-corrected density 
functional theory for sodium ion hydration. J Chem Theory Comput 11:2958-2967.

43. DiLabio GA, Johnson ER, Otero-de-la-Roza A (2013) Performance of conventional and dispersion-corrected density-functional theory methods for hydrogen bonding interaction energies. Phys Chem Chem Phys 15:12821-12828.

44. Budyka MF, Zyubina TS, Zarkadis AK (2002) Correlating ground and excited state properties: a quantum chemical study of the photodissociation of the $\mathrm{C}-\mathrm{N}$ bond in $\mathrm{N}$-substituted anilines. J Mol Struct (Theochem) 594:113-125.

45. Brinck T, Haeberlin M, Jonsson M (1997) A computational analysis of substituent effects on the $\mathrm{O}-\mathrm{H}$ bond dissociation energy in phenols: polar versus radical effects. J Am Chem Soc 119:4239-4244.

46. Delpuech A, Cherville J (1979) Relation entre la structure electronique et la sensibilité au choc des explosifs secondaires nitrés. Critère moléculaire de sensibilité II. Cas des esters nitriques. Propell Explos Pyrot 4:121-128.

47. Tan B, Long X, Li J, Nie F, Huang J (2012) Insight into shock-induced chemical reaction from the perspective of ring strain and rotation of chemical bonds. J Mol Model 18:5127-5132.

48. Hohenberg P, Kohn W (1964) Inhomogeneous electron gas. Phys Rev 136:B864-B871.

49. Rice BM, Hare JJ (2002) A quantum mechanical investigation of the relation between impact sensitivity and the charge distribution in energetic molecules. J Phys Chem A 106:1770-1783.

50. Politzer P, Murray JS (2014) Impact sensitivity and crystal lattice compressibility/free space. J Mol Model 20:2223-2230.

51. Murray JS, Concha MC, Politzer P (2009) Links between surface electrostatic potentials of energetic molecules, impact sensitivities and $\mathrm{C}-\mathrm{NO}_{2} / \mathrm{N}-\mathrm{NO}_{2}$ bond dissociation energies. Mol Phys 107:89-97.

52. Politzer P, Murray JS (2014) in: Brinck T (ed) Green Energetic Materials, Wiley, Chichester, UK, ch 3, 45-62.

53. Klapötke TM, Nordheiter A, Stierstorfer J (2012) Synthesis and reactivity of an unexpected highly sensitive 1-carboxymethyl-3-diazonio-5-nitrimino-1,2,4-triazolew. New J Chem 36:1463-1468.

54. Li H, Shu Y, Gao S, Chen L, Ma Q, Ju X (2013) Easy methods to study the smart energetic 
TNT/CL-20 co-crystal. J Mol Model 19:4909-4917.

55. Meng RH (2018) Study on thermal decomposition of HMX and RDX and its solution, Ph. D. Dissertation, North University of China, P42 68.

56. Zeman S, Atalar T, Friedl Z, Ju XH (2009) Accounts of the new aspects of nitromethane initiation reactivity. Centr Europ J Energ Mater 6:119-133. 


\section{Figures:}

Fig. 1 Structures of RDX and its compexes as well as model molecule of RDX

Fig. 2 Plots of RDG versus $\operatorname{sign}\left(\lambda_{2}\right) \rho$ of the complexes.

Fig. 3 Bond paths and critical points of AIM for RDX and complex.

Fig. 4 Surface electrostatic potentials of RDX and its complexes.

Fig. 5 Structures of the transition states for RDX and its complexes. 
Table 1 Intermolecular hydrogen-bonding interaction energy $\left(E_{\mathrm{int} .}(\mathrm{kJ} / \mathrm{mol})\right)$ in $\mathrm{RDX} \cdots \mathrm{THF}$,

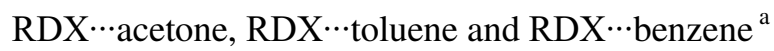

\begin{tabular}{|c|c|c|c|c|}
\hline & RDX $\cdots \mathrm{THF}$ & RDX $\cdots$ acetone & RDX $\cdots$ toluene & RDX $\cdots$ benzene \\
\hline BHandHLYP/6-311++G(2df,2p) & $-15.6(-12.9)$ & $-19.2(-16.8)$ & $-7.5(-5.8)$ & $-3.7(-1.5)$ \\
\hline B3LYP/6-311++G(2df,2p) & $-19.5(-16.3)$ & $-21.8(-17.5)$ & $-8.3(-6.5)$ & $-2.3(-1.8)$ \\
\hline MP2(full)/6-311++G(2df,2p) & $-13.7(-11.3)$ & $-22.0(-19.1)$ & $-7.2(-6.0)$ & $-2.6(-2.1)$ \\
\hline M06-2X/6-311++G(2df,2p) & $-12.5(-10.8)$ & $-20.6(-18.2)$ & $-6.9(-3.3)$ & $-2.4(-2.0)$ \\
\hline
\end{tabular}

${ }^{\mathrm{a}}$ The values in the parenthesis are BSSE-corrected ( $\left.E_{\text {int.(BSSE) }}\right)$. 
Table 2 Bond dissociation energy $(B D E(\mathrm{~kJ} / \mathrm{mol}))$ in the $\mathrm{N}-\mathrm{NO}_{2}$ bond

\begin{tabular}{|c|c|c|c|c|c|}
\hline \multirow{2}{*}{$\overline{\text { BHandHLYP/6-311++G(2df,2p) }}$} & \multicolumn{4}{|c|}{ RDX $\cdots$ THF RDX $\cdots$ acetone RDX $\cdots$ toluene RDX $\cdots$ benzene } & RDX \\
\hline & $\begin{array}{c}-235.8 \\
(-283.5)^{\mathrm{a}}\end{array}$ & $\begin{array}{c}-242.1 \\
(-289.1)^{\mathrm{a}}\end{array}$ & $\begin{array}{c}-233.6 \\
(-260.1)^{\mathrm{a}}\end{array}$ & $\begin{array}{c}-232.0 \\
(-267.6)^{\mathrm{a}}\end{array}$ & -227.5 \\
\hline B3LYP/6-311++G(2df,2p) & -197.2 & -203.5 & -189.5 & -186.3 & -185.7 \\
\hline MP2(full)/6-311++G(2df,2p) & -277.1 & -282.2 & -269.6 & -267.2 & -260.4 \\
\hline M06-2X/6-311++G(2df,2p) & -205.8 & -211.0 & -198.3 & -194.1 & -192.7 \\
\hline
\end{tabular}

${ }^{\text {a }}$ From the monomer RDX with the IEFPCM method. 
Table 3 Ring strain energy $\left(E_{\mathrm{SE}}(\mathrm{kJ} / \mathrm{mol})\right)$

\begin{tabular}{|c|c|c|c|c|c|}
\hline & \multicolumn{4}{|c|}{ RDX $\cdots$ THF RDX $\cdots$ acetone RDX $\cdots$ toluene RDX $\cdots$ benzene } & RDX \\
\hline BHandHLYP/6-311++G(2df,2p) & 97.2 & 99.5 & 102.5 & 95.7 & 96.3 \\
\hline B3LYP/6-311++G(2df,2p) & 108.3 & 103.1 & 103.0 & 102.5 & 100.9 \\
\hline MP2(full)/6-311++G(2df,2p) & 101.5 & 105.2 & 96.5 & 93.1 & 90.8 \\
\hline M06-2X/6-311++G(2df,2p) & 90.7 & 102.1 & 98.7 & 91.6 & 92.8 \\
\hline
\end{tabular}


Table 4 Barriers $\left(E_{\mathrm{a}}, \mathrm{kJ} / \mathrm{mol}\right)$ and corrected reaction rate constants $\left(k_{298.15 \mathrm{~K}, \mathrm{C}}, \mathrm{s}^{-1}\right.$, in parenthesis $)$ as well as the BDEs at the BHandHLYP/6-311++G(2df,2p), B3LYP/6-311++G(2df,2p), MP2(full)/6-311++G(2df,2p) and M06-2X/6-311++G(2df,2p) levels of theory.

\begin{tabular}{lcccc}
\hline & BHandHLYP & B3LYP & MP2(full) & M06-2X \\
\hline $\mathrm{C}_{3} \mathrm{H}_{8} \mathrm{O}_{2} \mathrm{~N}_{4} \cdots$ THF & $155.3\left(3.35 \times 10^{-14}\right)$ & 148.8 & 141.6 & 161.7 \\
$\mathrm{C}_{3} \mathrm{H}_{8} \mathrm{O}_{2} \mathrm{~N}_{4} \cdots$ acetone & $146.1\left(5.21 \times 10^{-13}\right)$ & 142.3 & 136.7 & 141.3 \\
$\mathrm{C}_{3} \mathrm{H}_{8} \mathrm{O}_{2} \mathrm{~N}_{4} \cdots$ toluene & $160.5\left(5.95 \times 10^{-17}\right)$ & 161.5 & 168.0 & 172.6 \\
$\mathrm{BDE}\left(\mathrm{C}_{3} \mathrm{H}_{8} \mathrm{O}_{2} \mathrm{~N}_{4}\right)$ & 173.6 & 168.7 & 179.2 & 178.7 \\
$\mathrm{CH}_{4} \mathrm{~N}_{2} \mathrm{O}_{2} \cdots$ THF & $170.5\left(3.01 \times 10^{-18}\right)$ & 160.1 & 188.0 & 173.5 \\
$\mathrm{CH}_{4} \mathrm{~N}_{2} \mathrm{O}_{2} \cdots$ acetone & $169.3\left(6.72 \times 10^{-17}\right)$ & 163.2 & 175.9 & 159.8 \\
$\mathrm{CH}_{4} \mathrm{~N}_{2} \mathrm{O}_{2} \cdots$ toluene & $182.3\left(6.52 \times 10^{-20}\right)$ & 181.5 & 197.5 & 192.8 \\
$\mathrm{BDE}\left(\mathrm{CH}_{4} \mathrm{~N}_{2} \mathrm{O}_{2}\right)$ & 209.1 & 208.1 & 258.0 & 249.8 \\
\hline
\end{tabular}



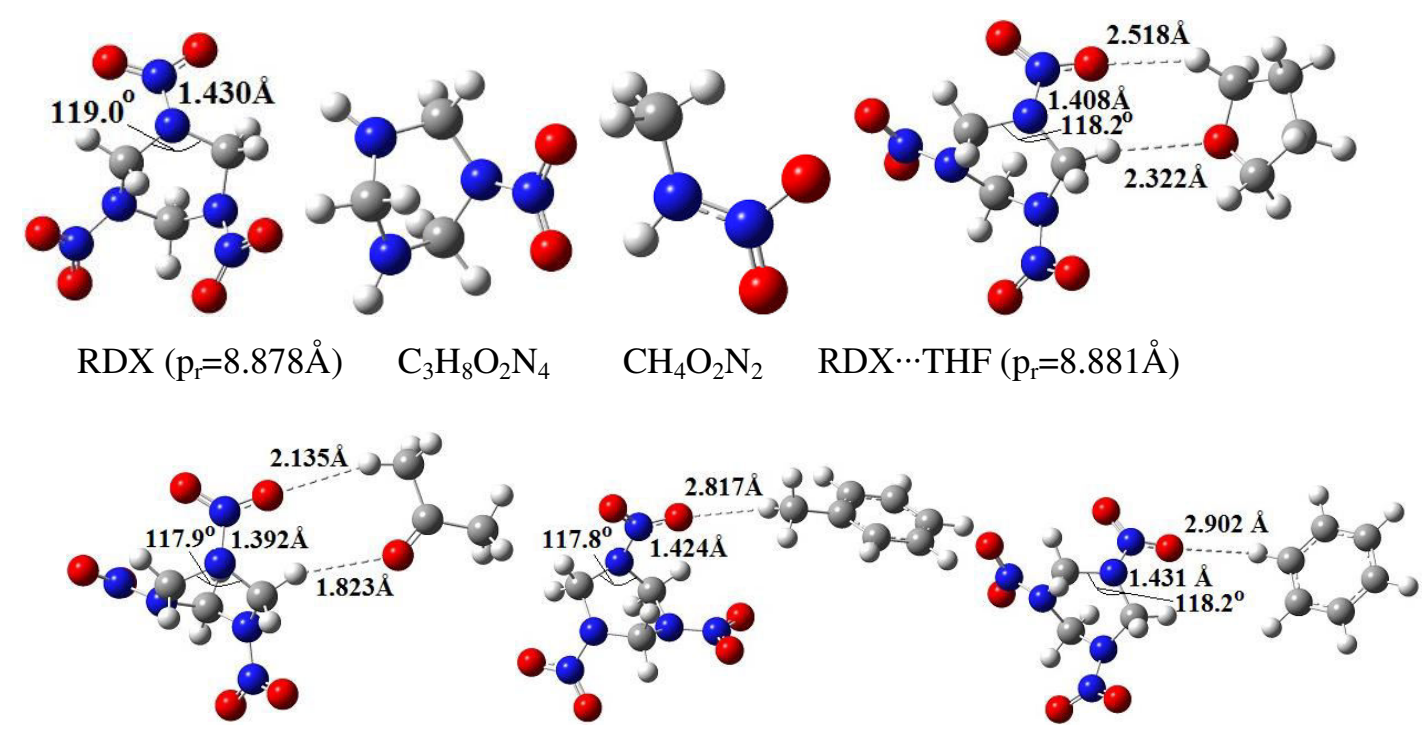

RDX $\cdots$ acetone $\left(\mathrm{p}_{\mathrm{r}}=8.875 \AA\right) \quad \mathrm{RDX} \cdots$ toluene $\left(\mathrm{p}_{\mathrm{r}}=8.870 \AA\right) \quad \mathrm{RDX} \cdots$ benzene $\left(\mathrm{p}_{\mathrm{r}}=8.882 \AA\right)$

Fig. 1 Structures of RDX and its compexes ( $\mathrm{p}_{\mathrm{r}}$ means the perimeter of the RDX ring) as well as model molecule of RDX at the BHandHLYP/6-311++G(2df,2p) level. 


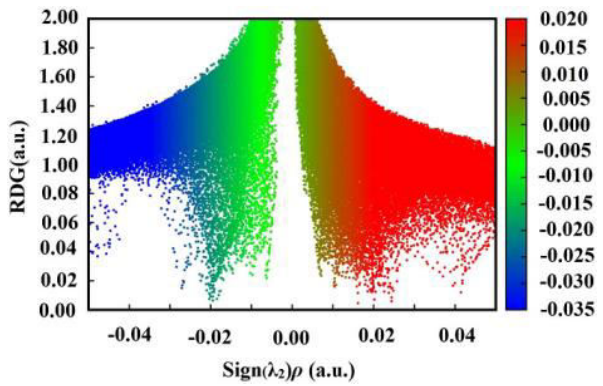

RDX $\cdots \mathrm{THF}$

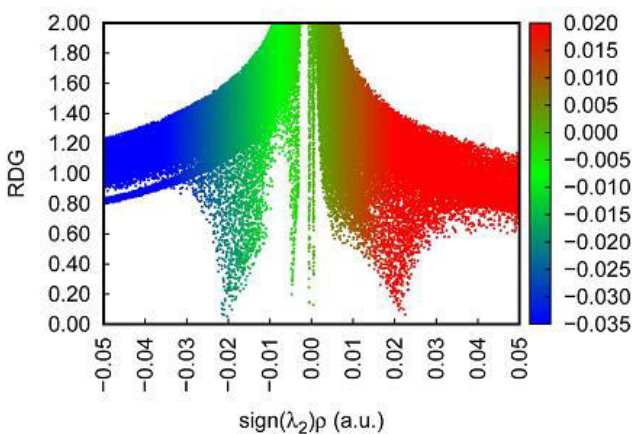

RDX $\cdots$ toluene

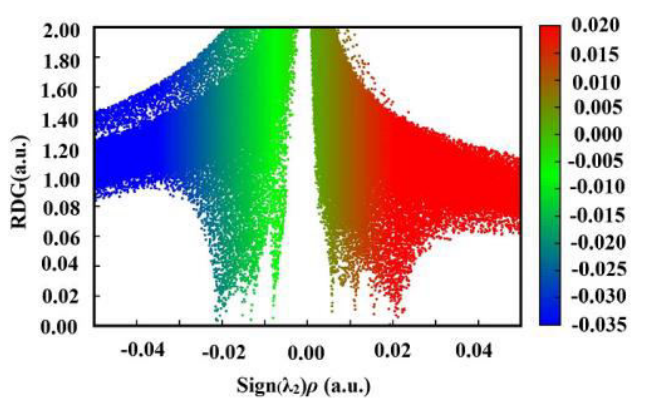

RDX *acetone

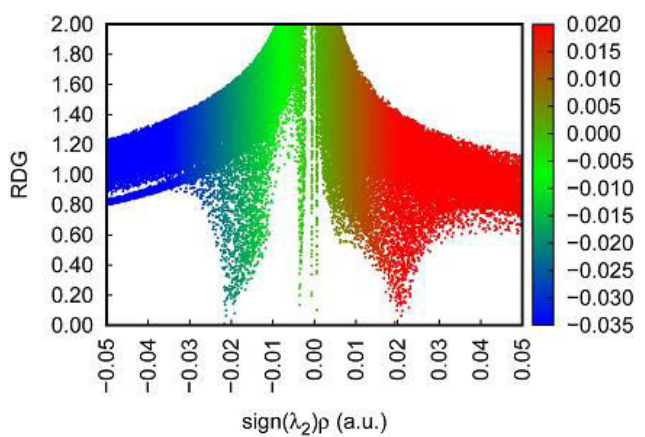

RDX ‥benzene

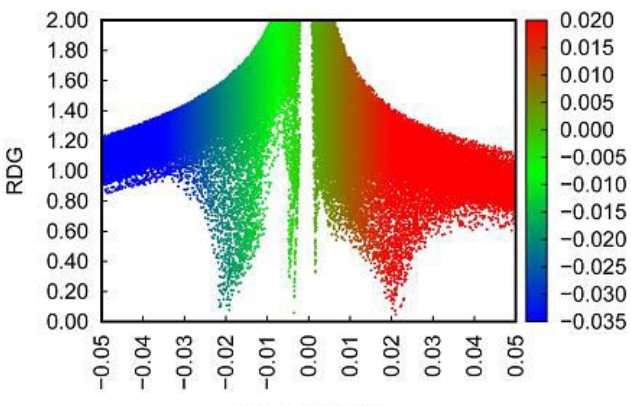

$\operatorname{sign}\left(\lambda_{2}\right) \rho($ a.u. $)$

\section{RDX $\cdots R D X$}

Fig. 2 Plots of RDG versus $\operatorname{sign}\left(\lambda_{2}\right) \rho$ of the complexes 


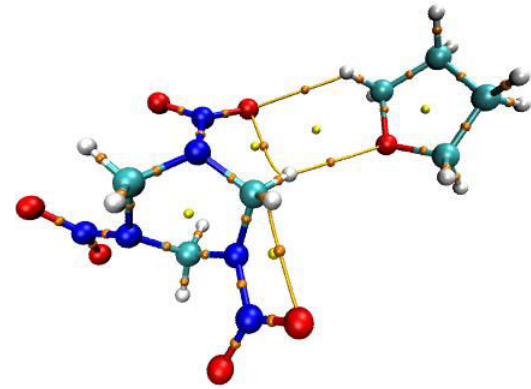

RDX $\cdots$ THF

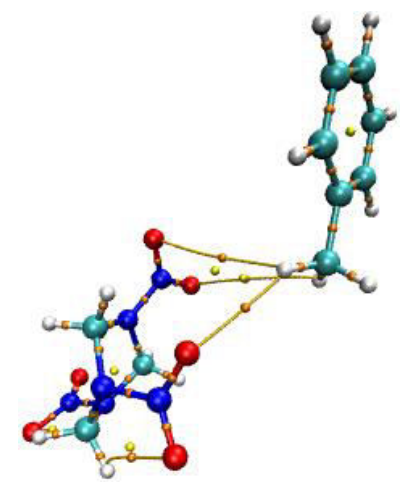

RDX $\cdots$ toluene
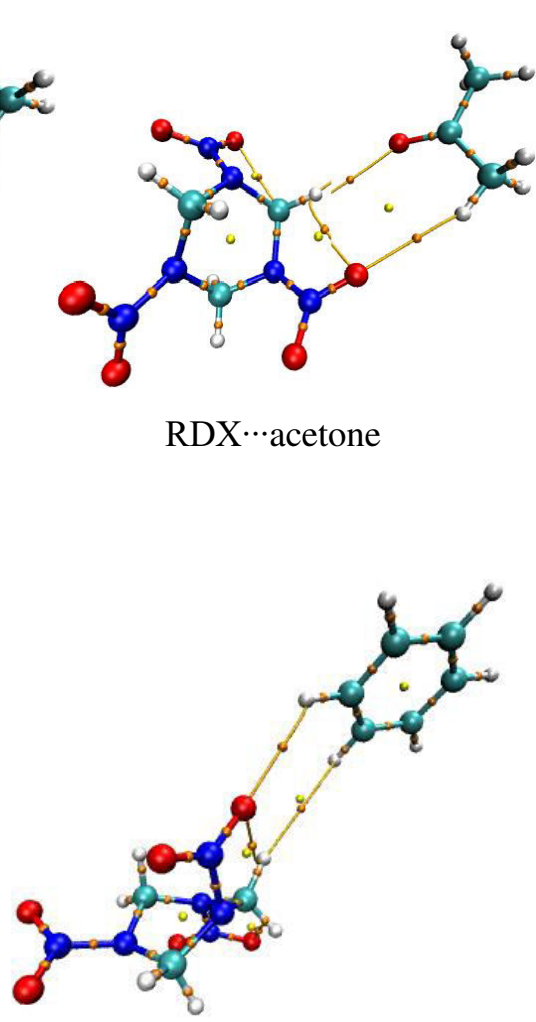

RDX $\cdots$ benzene

Fig. 3 Bond paths and critical points of AIM for RDX and complexes 


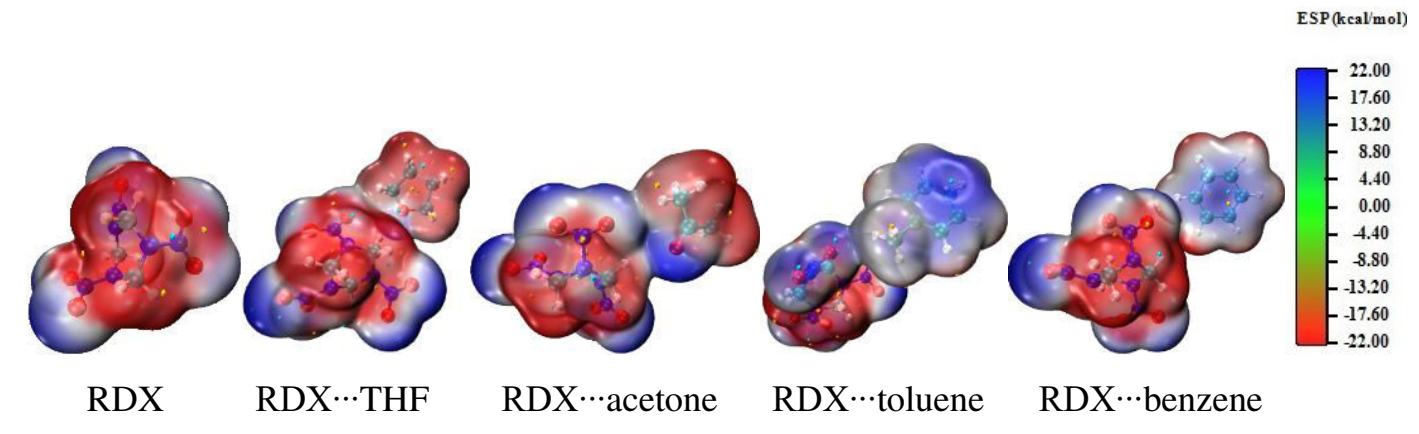

Fig. 4 Surface electrostatic potentials of RDX and its complexes 


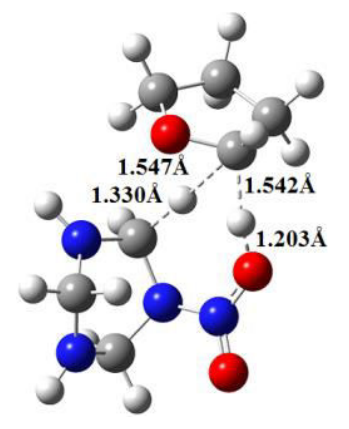

$\mathrm{TS}_{\mathrm{C} 3 \mathrm{H} 8 \mathrm{~N} 4 \mathrm{O} 2 \cdots \mathrm{THF}}$

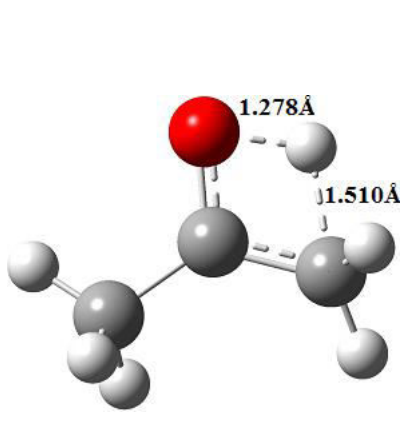

$\mathrm{TS}_{\text {acetone }}$

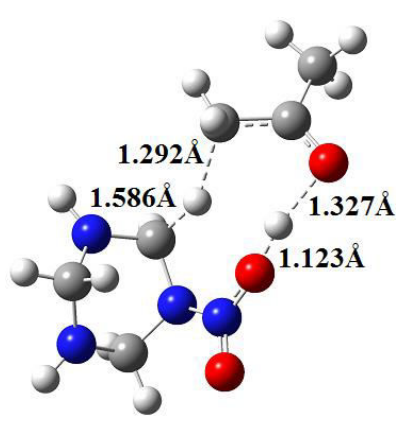

$\mathrm{TS}_{\mathrm{C} 3 \mathrm{H} 8 \mathrm{~N} 4 \mathrm{OO} 2 \cdots \text { acetone(enol) }}$

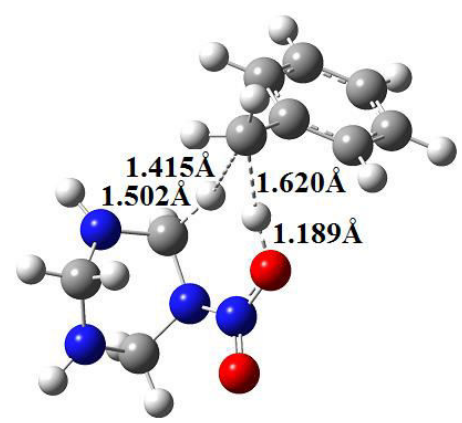

$\mathrm{TS}_{\mathrm{C} 3 \mathrm{H} 8 \mathrm{~N} 4 \mathrm{O} 2 \cdots \text { toluene }}$

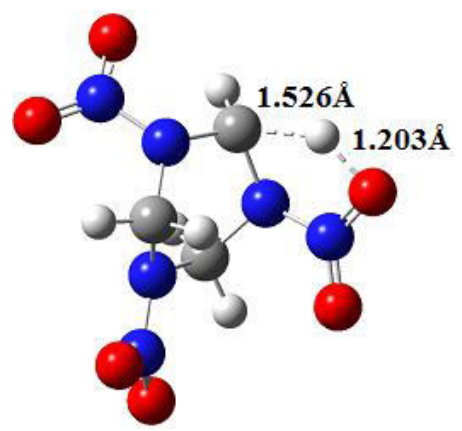

$\mathrm{TS}_{\mathrm{RDX}}$

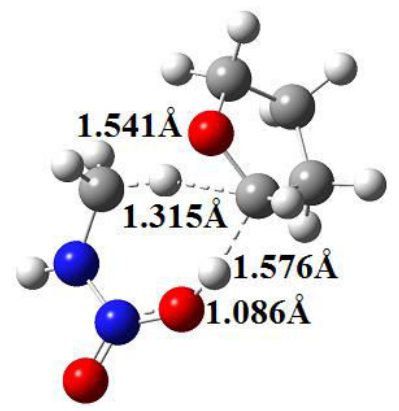

$\mathrm{TS}_{\mathrm{CH} 4 \mathrm{~N} 2 \mathrm{O} 2 \cdots \mathrm{THF}}$

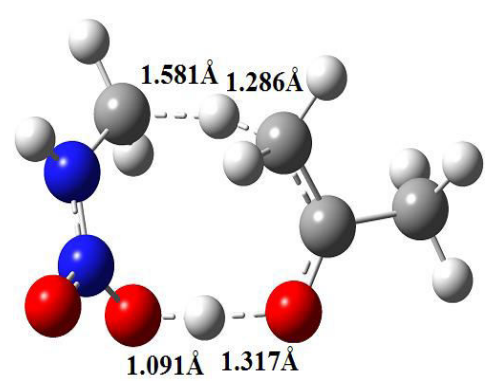

$\mathrm{TS}_{\mathrm{CH} 4 \mathrm{~N} 2 \mathrm{O} 2 \cdots \text { acetone(enol) }}$

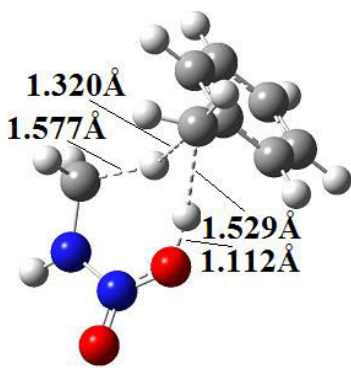

$\mathrm{TS}_{\mathrm{CH} 4 \mathrm{~N} 2 \mathrm{O} 2 \cdots \text { toluene }}$

Fig. 5 Structures of the transition states for the reactions of $\mathrm{C}_{3} \mathrm{H}_{8} \mathrm{~N}_{4} \mathrm{O}_{2}$ or $\mathrm{CH}_{4} \mathrm{~N}_{2} \mathrm{O}_{2}$ and THF, acetone, toluene(enol), as well as the intramolecular hydrogen transfer reaction of RDX. 


\section{Supplementary Files}

This is a list of supplementary files associated with this preprint. Click to download.

- AT.tif 